\title{
Management and Valorization of Urban Solid Waste: Landfills of the Batna City Case
}

\author{
Haddad Louiza ${ }^{1}$, Aouachria Zeroual ${ }^{2 *}$ \\ ${ }^{1}$ Laboratory of Natural Hazards and Territorial Planning (LARNAT), University Batna, Batna 05000, Algeria \\ ${ }^{2}$ Applied Energy Physics Laboratory (LPEA), University Batna, Batna 05000, Algeria
}

Corresponding Author Email: zeroual.aouachria@univ-batna.dz

https://doi.org/10.18280/ijdne.150507

Received: 10 May 2020

Accepted: 24 August 2020

\section{Keywords:}

urban solid waste, recovery, management principles, recycling, landfills, energy valorisation

\begin{abstract}
The treatment of urban solid waste represents, on the one hand, a current problematic drawing the intention of the authorities on their management and recovery through their recovery and recycling, and on the other hand, their gravity that they present on health and the environment. The purpose of this study is to provide solutions to the main questions regarding quantity, management principles, on which depend reliable management, landfilling techniques and their social, economic and environmental impacts. The methodology followed in this study is summarized by the following steps: review of the state of the art, field study and triage. The Batna landfill can, in its most unfavorable state, recycle 760,000 tons per year (between ores, paper, glass and plastic). Actually, recovery of recycled products accounted for only $23.89 \%$ for 2015 .
\end{abstract}

\section{INTRODUCTION}

During antiquity, man has exhausted his biodegradable raw materials in the living world. A lot of wastes were recycled. Food residues and manure used as fertilizers. The wild dump was being the first destination of human wastes. But at the time, it was of no consequence since all these wastes were inert or biodegradable. Rapid urbanization has caused the deterioration of the environment by the emergence of many development-related effects such as urban transport [1-4] and especially the so-called "waste dump" [5,6]. With the onset of the industrialization of these landfills begins to appear but most of the waste produced is absorbed by nature or diluted by discharges into rivers and/or the atmosphere. In modern times, social concentrations, the intensification of industrial activities, launch of new consumable products (plastic materials, polymers, textiles, synthetic dyes, household detergents...) have completely changed the management of these wastes. Residues accumulate, and even when they are biodegradable, they are rejected in such quantity that natural mechanisms of resumption, metabolisation and fermentation are strongly disturbed. As a result, waste pollution has become a serious concern today [7-9]. One of these most worrying consequences in the developing world is the problems of handling solid, liquid and toxic waste. Under solid waste, there are several types of waste according to the regulations of the Algerian country (Law No. 01-19 of 12/12/2001 relating to the management, control and disposal of waste); which they are classified in five groups: i- household and similar waste, iispecial waste, iii- special hazardous waste, iv- health care waste, and v- inert waste.

In Algeria, strong pressure on the environment has been registered, particularly in the field of municipal waste services. This situation is characterized by a deterioration of hygiene and public health despite the will and the great efforts of the State. In addition, Algeria aims through the modified law $03 / 83$ and supplemented by new orientations that now integrate Sustainable Development as a new dimension of this concern. It is the law $03 / 10$ of 2003 relating to the environment and the sustainable development. In addition to the general principles contained in Law 03/83, this new law introduces four other previously marginalized principles, namely: $i-$ The principle of preventive action and correction at the source of environmental damage, ii- The precautionary principle in case present scientific uncertainties, iii-The polluter pays principle to internalize the extra costs incurred by the community, ivAnd finally the principle of information and citizen participation [10]. The current state of the environment in Algeria is marked by five factors: $i$ - The problem of public health, ii- The insufficiency of the human and material means, iii- The saturation of the dumps, iv- The increase of the costs of elimination and $\mathrm{v}$ - The increase in total production and the ratio per inhabitant. Heterogeneity, the presence of biodegradable materials and the influence of external parameters, such as rainfall and temperature, are at the origin of chemical, physical and biological processes that influence one another and generating flows of gases and liquids as illustrated in Figure 1.

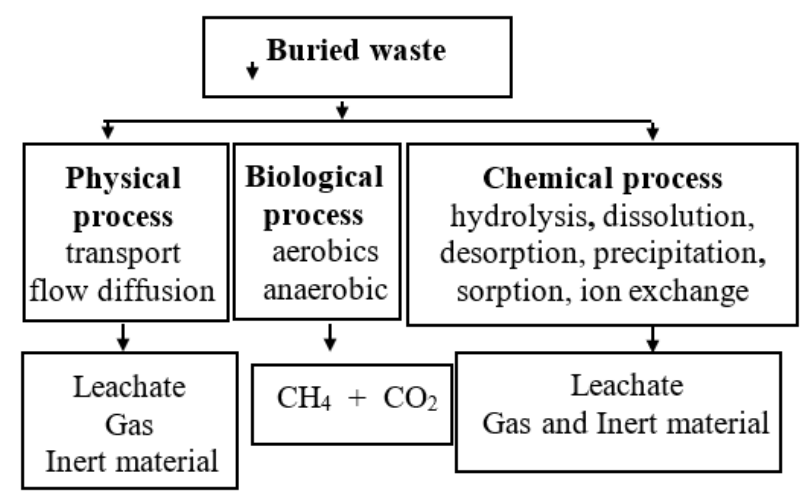

Figure 1. Physical, chemical and biological processes developing in a landfill 
To meet energy needs in order to significantly reduce local pollution and the greenhouse effect, for the environment preservation, exploration, and development of new sources of energy have been undertaken, particularly biomass energy [11]. This renewable energy widely available, inexpensive and clean is used to supplement non-renewable fossil fuels [12]. Agricultural waste is a usable energy potential [13], or by burning them directly to use the heat produced either by biogas and use of gas as an energy source [14]. The increasing on the slowing distention efficiency depends on the type of the waste [15].

According to the results obtained, the percentage of $\mathrm{CH}_{4}$ greatly increased by $15 \%$ after purification (i.e., a purification efficiency of $25 \%$ ), whereas the percentages of $\mathrm{CO}_{2}$ and $\mathrm{H}_{2} \mathrm{~S}$, on the contrary, decreased the first of $5 \%$ and the second $10 \%$. The results obtained are indications of the proper functioning of the purification process and the great importance of the biogas treatment, since it ensures a reduction in polluting elements $\left(\mathrm{CO}_{2}\right.$ and $\left.\mathrm{H}_{2} \mathrm{~S}\right)$ as well as intensification in $\mathrm{CH}_{4}$ concentration. Gaseous desulphu--rization by iron hematite has proved to be an effective method of conditioning, especially for the removal of $\mathrm{H}_{2} \mathrm{~S}$ [16]. Let's go back to our "housewife" situation. In its banality, it contains elements of frequent contradiction in our Western society. We produce organic waste that we must "treat", "value" to avoid nuisances and pollution. At the other end of the food chain: farmland hungry essential organic matter to replenish humus, essential to soil fertility. Of course, like many human situations, the problem is complex. If the solution probably involves the use of a minimum of technology, common sense is to consider finding a homecoming, or rather a return to the land.

Uncertainty affects the knowledge of waste deposit in Algeria. The estimates by the World Bank [16] and MATE in 2002 [17] show that much of this deposit consists of municipal waste (DM). The quantities of urban solid residues (RSU) produced annually in Algeria are estimated at 8.5 million tonnes. An Algerian, in urban areas, daily generates about 0.7 $\mathrm{kg}$ of waste. In the big cities, this production is close to $0.9 \mathrm{~kg}$ / day / inhabitant [18]. In lot of big cities, we assisted to mismanagement as seen in Figure 2.

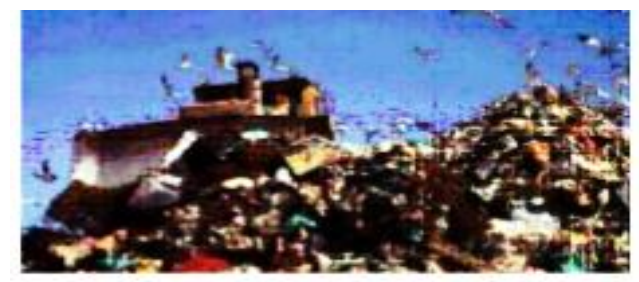

a. wild dumps

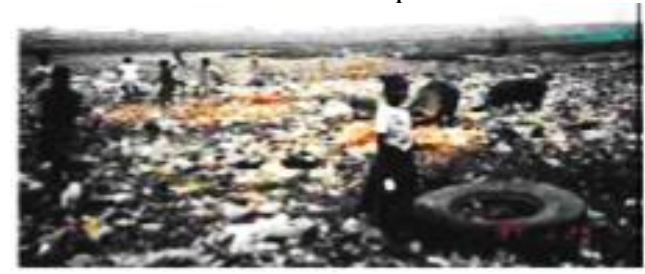

b. Children play in wild dumps

Figure 2. Example of mismanagement

The Figure 2 is alarming given the current management of waste, which can be summed up in a single slogan "all waste in landfill". It is far from the ideal of integrated management of RSU advocated for developing countries whose purpose is to avoid the streets littered with trash. At the Batna wilayas level, a quantity of $14,369.96$ tons of RSU, or 39.37 tons, is produced daily by the inhabitants of the city of Batna [19]. The majority of the Developing countries use landfill, between 90 to $97 \%$ of the waste produced respectively in Cameroon [20] and in Israel [21], little in the form of technical landfills respecting the environment. The distribution between the other sectors, recycling and incineration is not known for the P.E.D. However, incineration is rarely used because too sophisticated and too expensive, only $1 \%$ in Thailand [22].

Algeria is one of the countries included in sustainable development projects by the World Environment Organization. The choice of the city of Batna by this study is that it is the first city which has a technical landfill center and a favorable space for its environmental location. In addition to this, this location will allow the inhabitants of the surrounding villages to obtain electric energy which can be generated from the biomass of this center.

In our work, we analyze different processes of valorization compatible with the nature of urban solid wastes of the city of Batna and to determine directives to be taken by the communal decedents.

\section{SITUATION OF THE STUDY AREA}

\subsection{Presentation of the city of Batna}

The wilaya of Batna is bounded on the north by the wilaya of Mila, Oum El Bouaghi and Setif, on the east by the wilaya of Khenchela, to the west by the wilaya of M 'Sila and on the south by the wilaya of Biskra Figure 3. The climate of the wilaya is semiarid. The winter is cold with temperatures ranging from $0^{\circ} \mathrm{C}$ to $5^{\circ} \mathrm{C}$ and the summer is very hot with temperatures that can go up to $45^{\circ} \mathrm{C}$ in the shade.

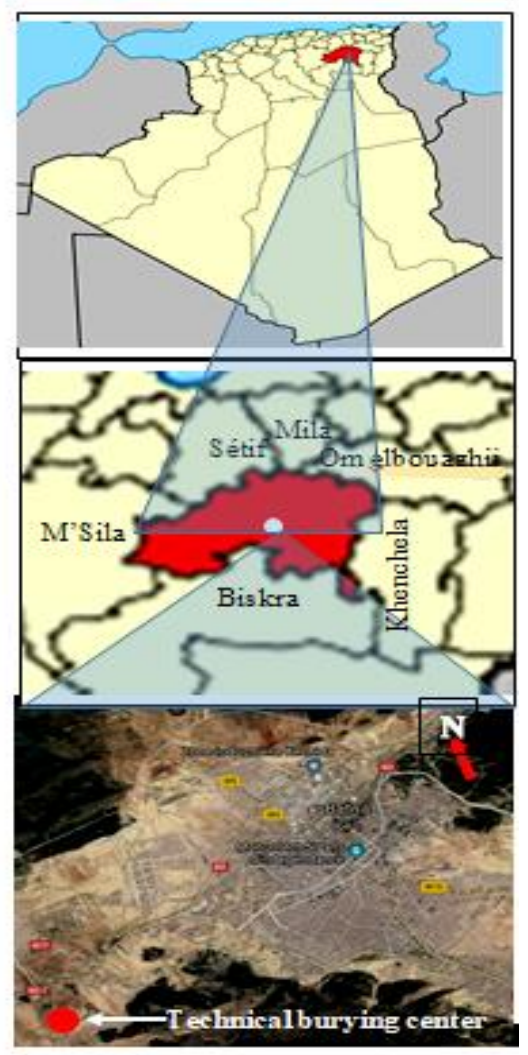

Figure 3. Geographic location of the study area and le location of Landfill Technic Centre (LTC) 


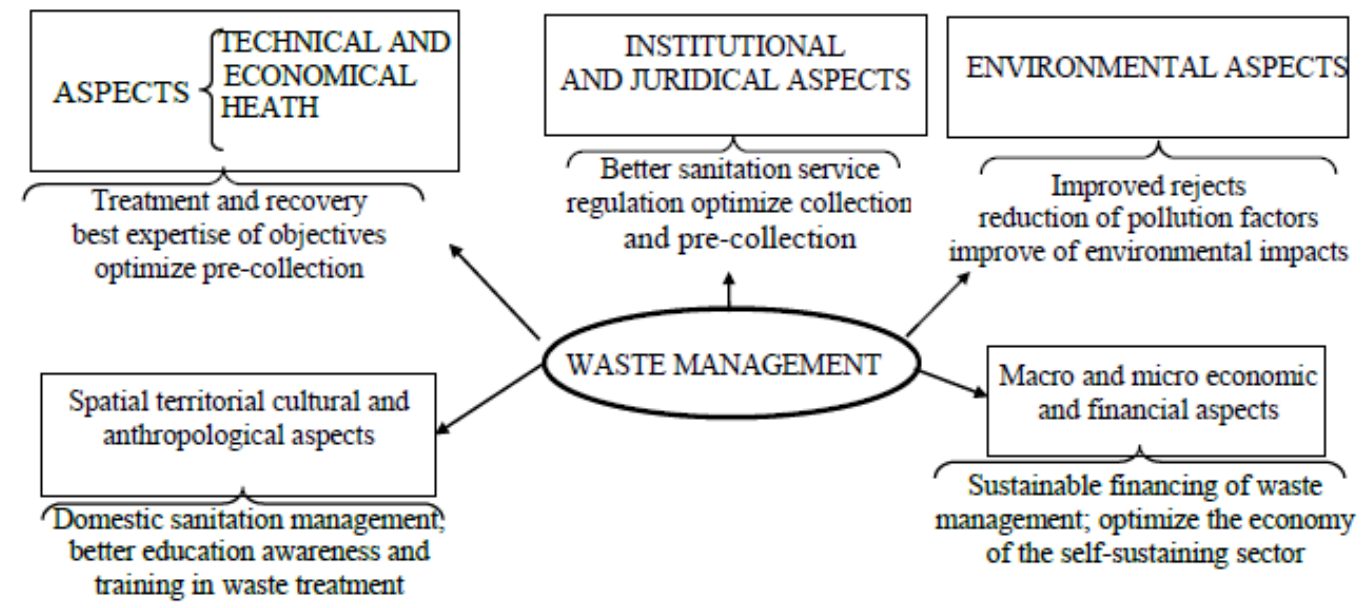

Figure 4. Five main aspects of waste management

The economy of the wilaya is mainly focused on agriculture. The industry is in full swing development partly due to the presence of important mineral resources: the wilaya of Batna also important tourist sites including the sites of Timgad, Ghoufi Gorge, hot springs natural and many other historic sites. To ensure the best management of solid urban waste and guarantee sustainable development in terms of energy we must apply five main aspects of treatment shown in Figure 4.

\subsection{Statement on the landfill technic centre (LTC)}

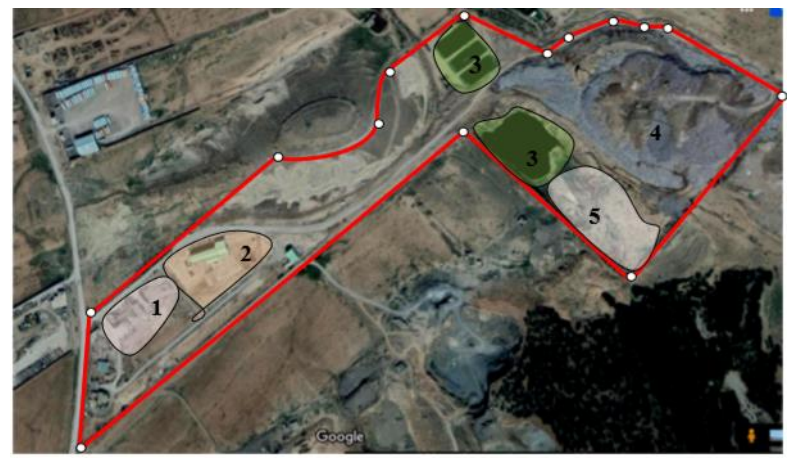

Figure 5. View and limitations area of the Batna landfill center: 1-administrative block, 2- sorting block, 3-leachate ponds, 4-waste lockers, 5 -extension (https://maps.google.com/map)

It is a center designed, on an area of $25 \mathrm{ha}$, to conserve waste without damaging the pollution of the environment. It is commissioned in 2006 for an operation that will last between 20-25 years. It is located in the town of CHAABA $9 \mathrm{~km}$ southwest of the city of Batna, Figure 5. It receives 400 tons per day of urban waste, assimilated and hospital waste that is incinerated directly. It is the only center at the national level that receives such types of waste. It has 8 programmed bins and at its entrance is a rocker for landfill trucks to quantify the waste over time as it is equipped with a radioactive control system. This center equipped with the latest techniques in recycling, waste collection and processing, and a daily processing capacity of 400 tons of waste. It is also recently equipped with a sorting center and an industrial waste disposal center which are also operational at this Technical landfill. The population of Batna commune produces about 40 tons of urban waste per day, not counting the part that is dumped by the private sector. This amount added to that of the common
Echaaba is received by the technique Batna discharge, which causes the emission of greenhouse gas (biogas) and large volumes of leachate currently untreated could damage the Adriatic groundwater of the region.

\subsection{Problem of household waste}

The problem posed by waste coming especially from the urban environment relates essentially to their management. This is summarized in five main aspects that can be schematized in Figure 4. It should be noted that the pollution of the environment by urban solid waste represents a major challenge for urban populations in general.

It should be noted that the Pollution of the environment by urban waste represents a major challenge for urban populations in general. Policy makers have clearly understood that the environmental problem and its relation to sustainable development are not only ecological but also economic and environmental and above all entertaining sites of these wastes that require controlled management $[23,24]$. These figures show us that there is still a lot of effort to achieve in terms of recycling, but especially reduction at source the quantity of waste we produce. Act upstream: the best waste is the one that is not produced. Waste management is first and foremost a source control through the 3Rs rule: reduce, reuse, and recycle. Various waste conversion processes are [25]: (i) - thermal conversion [(incineration, pyrolysis, gasification, energy production from waste derived fuels (RDF)], (ii)- biological conversion (anaerobic digestion /biogas and composting) and (iii)- landfilling with gas recovery MSW treatment techniques as well as typical reaction products are presented.

\section{VALOTIZATION OF URBAN WASTE}

The recovery of waste heat from product gas is an efficient method to increase the energy efficiency of a thermal device. With this approach, heat can be recovered and transferred to be utilized in other processes. The use of municipal waste, buried in the ground, to produce fuel and energy has many advantages [26] since its use avoids the emission of greenhouse gases. To benefit, many investigations have been carried out to convert this waste into fuel $[27,28]$. The burial of municipal solid waste causes decomposition under anaerobic conditions and then generates a mixture of gases $\left(\mathrm{CH}_{4}+\mathrm{CO}_{2}\right)$ that is collected and its methane is burned, to 
reduce the greenhouse effect and produce electrical energy. The $\mathrm{CH}_{4}$ fate is generated according to the mechanism schematized in Figure 6. Energy recovery appears as an interesting solution in the face of the multiplication of waste, of course, but also in the face of energy and climate issues. In order to achieve the maximum economic benefit, Algeria strives to encourage investment in recycling and recovery through different processes. The main processes used are material recovery and energy recovery. However, the operation that comes to the forefront of any valuation is essential because it can direct the investment towards appropriate niches. This is the sorting and pre-sorting of different wastes. This operation defines the recyclable and unrecyclable materials $[29,30] . \mathrm{CH}_{4}$ emissions from waste incineration largely depend on the continuity of the incineration process, the technology used and management practices. The most detailed observations were made in Japan (GIO, 2004) where the following $\mathrm{CH}_{4}$ emission factors, based on technology and procedure, were obtained.

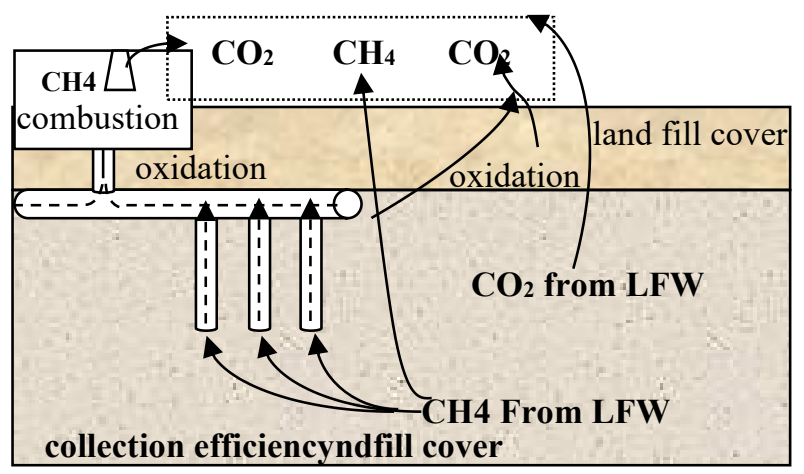

Figure 6. Fate of LFG emission generated from land filled organic waste

\section{APPLICATION TO BIOGAS COMBUSTION}

\subsection{Introduction}

The processes of combustion are widely used today to meet the energy needs of humanity. They are used to convert a large quantity of waste, biogas, into simple elements of the $\mathrm{CO}_{2}$, $\mathrm{H}_{2} \mathrm{O}$ and heat type. This heat of combustion resulting from the oxidation of the fuel, if it is recovered, it will constitute an energetic vector to supply turbines of the electric power stations or as cogeneration.

Combustion can be defined as an exothermic chemical reaction in which the combustible material is converted to give carbon dioxide and water with oxygen in the air. The combustion reaction can then be written in the form of an equation connecting the reagents and the products which result and which, depending on the pressure and temperature conditions may be in liquid or vapour form.

$$
\text { Fuel }+\mathrm{O}_{2} \rightarrow\left(\mathrm{CO}_{2}\right)+\left(\mathrm{H}_{2} \mathrm{O}\right)+\mathrm{Q}
$$

where, $\mathrm{Q}$ is the heat released during the reaction.

\subsection{Application la combustion du biogas}

In most cases, the combustion is carried out in air, it should be considered that the latter contains $21 \%$ by volume or $23 \%$ by weight of oxygen, the remainder being practically nitrogen which does not interfere with combustion and should be rejected as such in the flue gas. The combustion reaction (1) with the air thus becomes:

$$
\text { Fuel }+\left(\mathrm{O}_{2}+3.76 \mathrm{~N}_{2}\right) \rightarrow \mathrm{CO}_{2}+\mathrm{H}_{2} \mathrm{O}+3.76 \mathrm{~N}_{2}+\mathrm{Q}
$$

It should be noted that combustion processes are never perfect. In reality, several intermediate products are formed during actual combustion. They are nevertheless important in practice, especially for pollution problems to take into account. Indeed, when air is the oxidant, the nitrogen that is there can oxidize when there is an excess of oxygen to produce NOx emissions of nitrogen oxides, which are partly responsible acid rain. Also, when the air supplied is insufficient for incomplete combustion, the formation of carbon monoxide $(\mathrm{CO})$ is very dangerous. A $0.2 \% \mathrm{CO}$, content in the air, causes death in less than half of an hour. For larger air gaps, there may still be unburned hydrocarbons, or carbon in the form of graphite. After estimating the resulting products, the equation of the reaction of hydrocarbons with air is written in form [31]:

$$
\begin{gathered}
\text { a1Fuel1 + a2Fuel2 + a3Fuel3 + a 4Fuel4 + bO } \mathrm{F}_{2}+\mathrm{cN}_{2} \\
\rightarrow \mathrm{NP}\left[\left(\mathrm{A}\left(\mathrm{H}_{2}\right)+\mathrm{B}\left(\mathrm{H}_{2} \mathrm{O}\right)+\mathrm{C}\left(\mathrm{CO}_{2}\right)+\mathrm{D}\left(\mathrm{N}_{2}\right)+\mathrm{E}\right.\right. \\
(\mathrm{O})+\mathrm{F}\left(\mathrm{O}_{2}\right)+\mathrm{G}\left(\mathrm{O}_{3}\right)+\mathrm{H}(\mathrm{H})+\mathrm{P}(\mathrm{OH})+\mathrm{Q}(\mathrm{CO})+ \\
\quad \mathrm{R}(\mathrm{C})+\mathrm{S}\left(\mathrm{CH}_{4}\right)+\mathrm{T}(\mathrm{NO}) \\
+\mathrm{V}\left(\mathrm{NO}_{2}\right)+\mathrm{W}\left(\mathrm{NH}_{3}\right)+\mathrm{X}\left(\mathrm{HNO}_{3}\right)+\mathrm{Y}(\mathrm{HCN})+\mathrm{Z}(\mathrm{N})
\end{gathered}
$$

where, A, B, C, D, E, etc. are the mole fractions of the products. NP is the total number of moles of the product. a1, a2, a3, a4, $\mathrm{b}, \mathrm{c}$, are the numbers of mole of fuel and the oxidant. One of the important parameters, characterizing a combustion reaction, is its heat of action, which is necessary to calculate the temperature of the maximum temperature (adiabatic flame or combustion temperature, TAF) and that of the composition of the products. These calculations are based on the thermodynamics principles, see details in the work [32].

The biogas used in these calculations is estimated to have the proportions: $\left(50 \% \mathrm{CO}_{2}\right.$, and $\left.50 \% \mathrm{CH}_{4}\right)$. The concentrations of the products of combustion including of course the pollutants are calculated at the chemical equilibrium.

$$
\begin{gathered}
\mathrm{CO}_{2}+0.5 \mathrm{CH}_{4}+\mathrm{a}\left(\mathrm{O}_{2}+3.76 \mathrm{~N}_{2}\right) \rightarrow \mathrm{NP}\left[\left(\mathrm{A}\left(\mathrm{H}_{2}\right)+\right.\right. \\
\mathrm{B}\left(\mathrm{H}_{2} \mathrm{O}\right)+\mathrm{C}\left(\mathrm{CO}_{2}\right)+\mathrm{D}\left(\mathrm{N}_{2}\right)+\mathrm{E}(\mathrm{O})+\mathrm{F}\left(\mathrm{O}_{2}\right)+\mathrm{G} \\
\left(\mathrm{O}_{3}\right)+\mathrm{H}(\mathrm{H})+\mathrm{P}(\mathrm{OH})+\mathrm{Q}(\mathrm{CO})+\mathrm{R}(\mathrm{C})+\mathrm{S}\left(\mathrm{CH}_{4}\right) \\
+\mathrm{T}(\mathrm{NO})+\mathrm{V}\left(\mathrm{NO}_{2}\right)+\mathrm{W}\left(\mathrm{NH}_{3}\right)+\mathrm{X}\left(\mathrm{HNO}_{3}\right)+\mathrm{Y} \\
(\mathrm{HCN})+\mathrm{Z}(\mathrm{N})
\end{gathered}
$$

The biogas composition decreases the adiabatic end-ofcombustion temperature, and to apply the same temperature as in the work [31], it is assumed that biogas is preheated because of unavailability of low temperature constants.

\section{RESULTS AND DISCUSSIONS}

Numerical results obtained during the simulations have been summarized in Table 1. The validating of the model is carried out with the results of the work [32]. The comparison is made for the pure methane, for $\mathrm{T}=2176.213 \mathrm{~K}$ and $\lambda=1$ see Table 1 . The results are in good agreement, especially in the concentrations of pollutants.

The code is now ready to be used for the combustion of biogas which is in fact only methane $\left(\mathrm{CH}_{4}\right)$ diluted at $50 \%$ with carbon dioxide $\left(\mathrm{CO}_{2}\right)$. Biogas, in view of its chemical 
composition, behaves in combustion exactly like methane, as the fuel part is $\mathrm{CH}_{4}$, but the presence of $\mathrm{CO}_{2}$ in high concentration lowers the calorific power and can contribute to the dissociation of $\mathrm{CO}_{2}$ at a high-level temperature. The effects of adiabatic temperature (Tad) and stoichiometry $(\lambda)$ on different emissions are presented.

Table 1. Results confrontation [32, 33]

\begin{tabular}{cccc}
\hline Products & [32] results & [33] results & Present results \\
\hline $\mathrm{H}_{2}$ & $0.177410^{-1}$ & $0.178010^{-1}$ & $0.178010^{-1}$ \\
$\mathrm{H}_{2} \mathrm{O}$ & $0.164810^{0}$ & $0.1648910^{0}$ & $0.164910^{0}$ \\
$\mathbf{C O}_{2}$ & $\mathbf{0 . 7 9 0 5} \mathbf{1 0}^{-1}$ & $\mathbf{0 . 7 9 2 0 6 ~ 1 0}$ & $\mathbf{0 . 7 9 0 6 ~ 1 0}$ \\
$\mathrm{N}_{2}$ & $0.692310^{-1}$ & $0.6924610^{0}$ & $0.692410^{00}$ \\
$\mathrm{O}$ & $0.206710^{-4}$ & $0.210010^{-4}$ & $0.216210^{-4}$ \\
$\mathrm{O}_{2}$ & $0.821010^{-4}$ & $0.831710^{-4}$ & $0.831910^{-4}$ \\
$\mathrm{O}_{3}$ & $0.790510^{-13}$ & $0.798510^{-13}$ & $0.798510^{-13}$ \\
$\mathrm{H}$ & $0.646210^{-3}$ & $0.653710^{-3}$ & $0.6546710^{-3}$ \\
$\mathrm{OH}$ & $0806410^{-3}$ & $0.8132310^{-3}$ & $08132310^{-3}$ \\
$\mathbf{C O}$ & $\mathbf{0 . 4 3 6 0 1 0 ^ { - 3 }}$ & $\mathbf{0 . 3 1 5 5 8 ~ 0 ^ { - 1 5 }}$ & $\mathbf{0 . 4 3 8 2 0} 10^{-3}$ \\
$\mathrm{C}$ & $0.312810^{-15}$ & $0.231110^{-13}$ & $0.315510^{-15}$ \\
$\mathrm{CH}$ & $0.236610^{-13}$ & $0.231110^{-13}$ & $0.231210^{-13}$ \\
$\mathrm{~N}$ & $0.000010^{0}$ & $0.777110^{-10}$ & $0.077710^{-10}$ \\
$\mathrm{NO}$ & $0.230610^{-3}$ & $0.232110^{-03}$ & $0.232210^{-3}$ \\
$\mathrm{NO}_{2}$ & $0.561910^{-8}$ & $0.563810^{-08}$ & $0.563810^{-8}$ \\
$\mathrm{NH}_{3}$ & $0.314410^{-7}$ & $0.31001-07$ & $0.310510^{-7}$ \\
$\mathrm{HNO}_{3}$ & $0.114410^{-14}$ & $0.113510^{-14}$ & $0.113810^{-14}$ \\
$\mathrm{HCN}^{-14}$ & $000010^{0}$ & $0.419510^{-11}$ & $.419510^{-11}$ \\
\hline
\end{tabular}

\subsection{Flame temperature effect on different emissions}

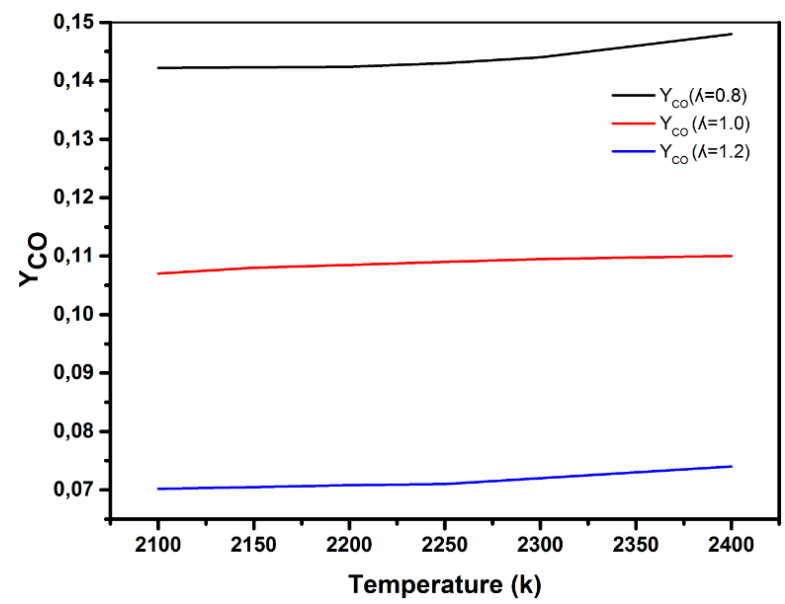

a. $\mathrm{CO}$

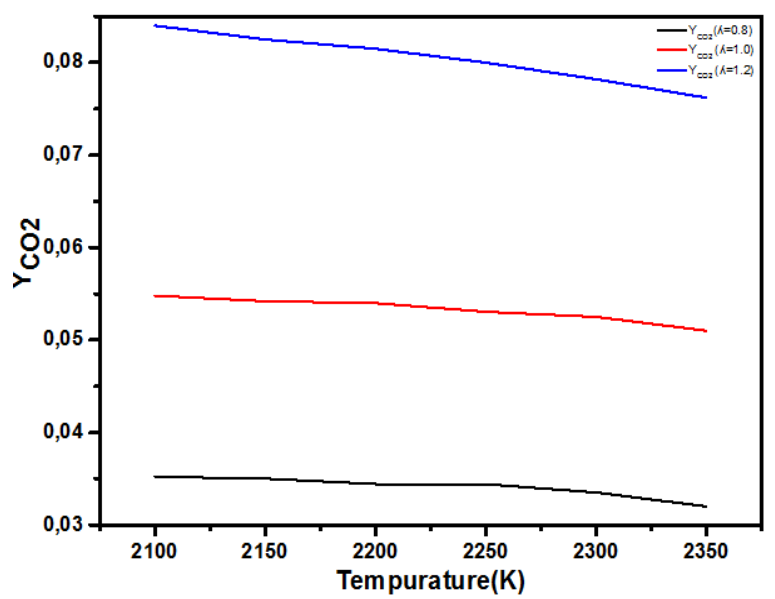

b. $\mathrm{CO}_{2}$

Figure 7. Mass fraction evolution of $\mathrm{CO}$ and $\mathrm{CO}_{2}$ vs flame temperature
The increase in flame temperature leads to an increase in the rate of $\mathrm{CO}$ formation as shown in Figure 7, and also a decrease in $\mathrm{CO}_{2}$, Figure 8. This is explained by the phenomenon of dissociation of $\mathrm{CO}_{2}$ at high temperature. When the concentration of biogas in $\mathrm{CO}_{2}$ is quite high, the biogas with high temperature of combustion (of the order of $2000^{\circ} \mathrm{C}$ ), the $\mathrm{CO}_{2}$ of the biogas can be a source of $\mathrm{CO}$, which requires another process of its reduction.

Figure 8 shows that increasing the temperature increases the production of $\mathrm{NO}$ and $\mathrm{NO}_{2}$. It is obvious that the thermal $\mathrm{NO}_{\mathrm{X}}$ is a function of the temperature. This production is based on the nitrogen of the air converted into $\mathrm{NO}_{\mathrm{X}}$ at high temperatures. These emissions are responsible for the formation of acid rain.

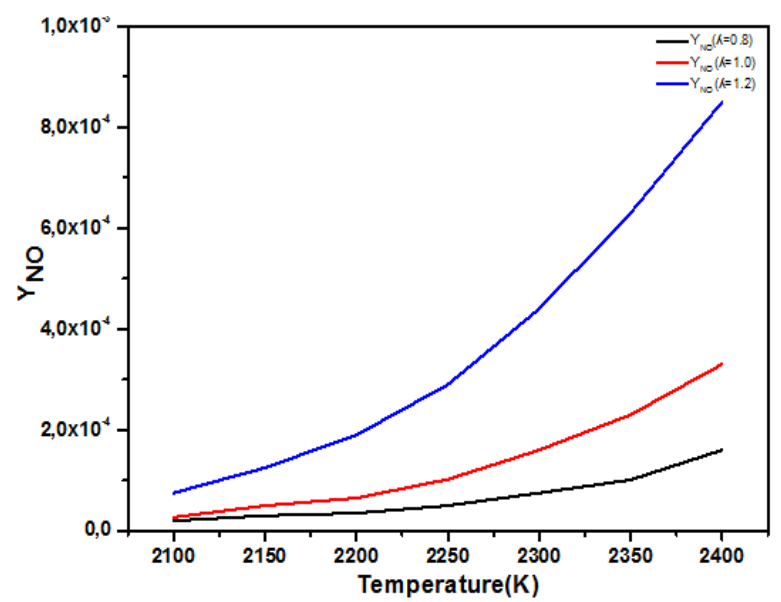

a- NO

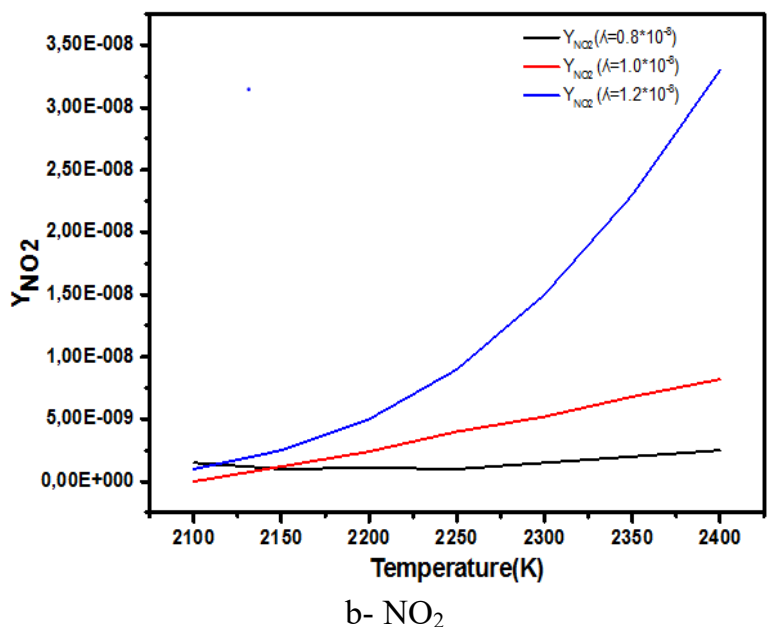

Figure 8. Mass fraction evolution of $\mathrm{NO}$ and $\mathrm{NO}_{2}$ vs flame temperature

\subsection{Equivalence ratio effect on emissions}

Figures 9 and 10, show a significant increase in $\mathrm{CO}_{2}$ and $\mathrm{H}_{2} \mathrm{O}$ when the equivalence ratio $\lambda$ is increased. This explains the "burnout" of $\mathrm{CO}$ and $\mathrm{H}_{2}$, which is in line with the pattern of Figure $7 \mathrm{a}$ and Figure 9.

The NOx increases by increasing $\lambda$, which explains the conversion of $\mathrm{NH}_{3}$ and $\mathrm{HCN}$ into fuel-NOx in addition to the thermal NOx which has as source of the $\mathrm{N}_{2}$ of the combustion air.

In Figure 11, we see that the curve has flattened towards $\lambda$ $=0.7$, which means that the evolution approaches a minimum which represents a great interest for optimization of the combustion system. 


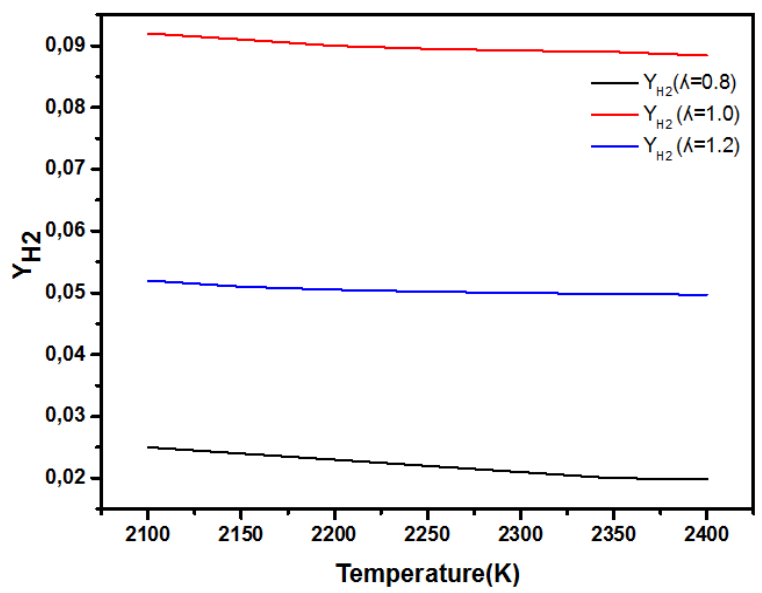

Figure 9. $\mathrm{Y}_{\mathrm{H} 2}$ variation as a function of temperature

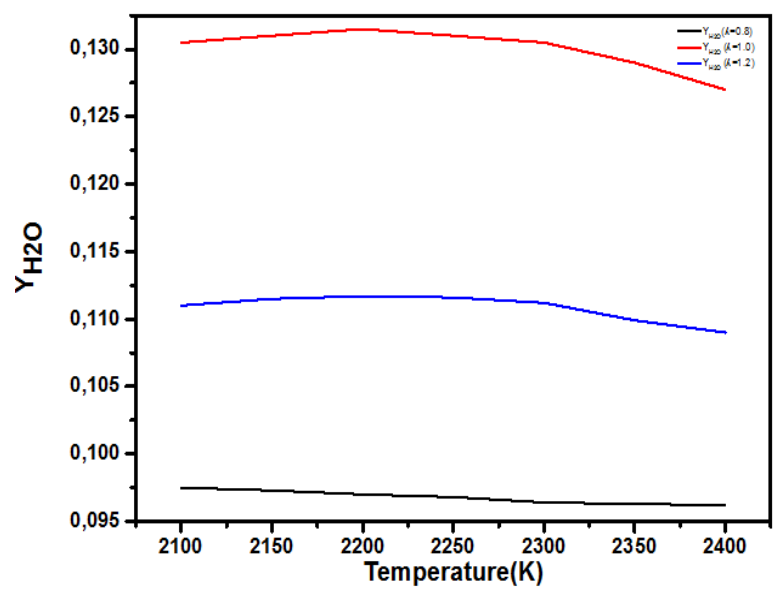

Figure 10. $\mathrm{H}_{2} \mathrm{O}$ variation as a function of temperature

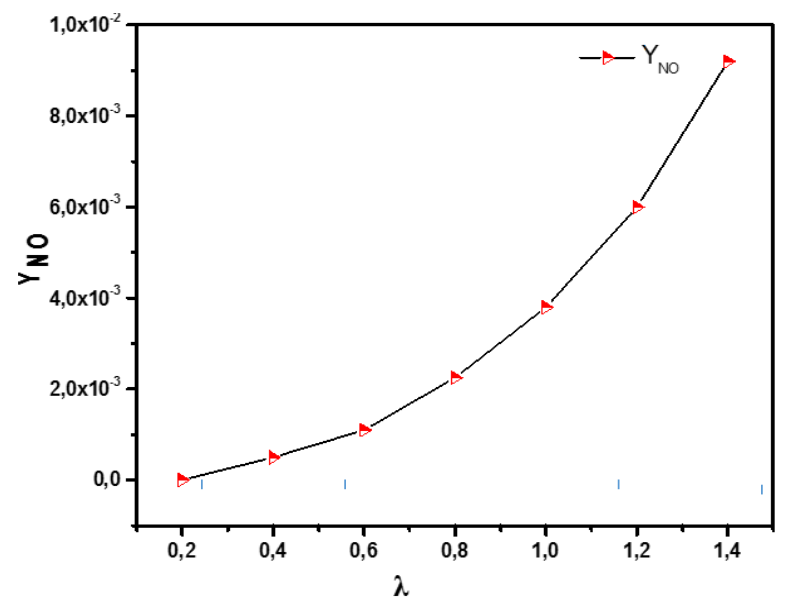

Figure 11. Variation of $\mathrm{NO}$ as a function of $\lambda$

In summary, our thermodynamic analysis, through the evolution of the products of the combustion of biogas obtained from urban solid waste, shows that this fuel whose calorific value is interesting, by adjusting the parameter $\lambda$ to decrease the $\mathrm{CO}_{2}$ and it can be an alternative source of energy without risk to the environment. In Addition, by safeguarding the ecological and climatological system, we contribute to the sustainable development of the surrounding villages. Indeed, the two villages near the centre technical landfill, El biar and Lamberidi, can be supplied with electrical energy produced from this source.

\section{CONCLUSION}

During this work, we discussed the study of solid waste and the different treatment techniques, especially the energetic recovery of these wastes. In conclusion, we can say that waste must be regarded not only as a nuisance, but also as an important source of renewable energy, especially the biogas. The conclusions drawn from this study are presented for the general case of solid waste treatment and the impact of the combustion of biogas resulting from this waste as a less polluting alternative energy source.

Solid waste can be a very important green energy resource. The partial substitution of fossil fuels by renewable energies will prolong the availability of these energies and conserve the environment;

- The safeguarding of the environment is a vital thing for the welfare of man and public health. Solid waste poses a major environmental problem which makes their treatment and more than a necessity;

- Since solid waste must be treated to safeguard the environment.

The main results of this study are especially concerned the combustion of biogas, if not optimized, poses new environmental problems as the problem of harmful emissions, $\mathrm{NOx}, \mathrm{CO}_{2}, \mathrm{CO}$, on the human health and the air quality. Our calculation program has a good way of optimizing combustion in order to reduce harmful emissions, notably by optimizing the temperature and the equivalence ratio $\lambda$.

Since this field of study is very large and very important. This study can be supplemented by other studies taking into account:

- Development of the chemical mechanism for combustion biogas; - Filtration;

- Optimization of technology combustion systems to save the human health and the environment.

\section{REFERENCES}

[1] Haddad, L., Haddad, D., Aouachria, Z. (2016). Noise pollution analyses in urban site: Batna city case. International Journal for Traffic and Transport Engineering, 6(3): 253-264. http://dx.doi.org/10.7708/ijtte.2016.6(3).02

[2] Kallel, A., Ksibi, M., Bendhia, H., Khelifa, N. (2018). Recent advances in Environnemental Science from the Euro-Mediterranean and Surrounding Regions. Springer int. Publishing AG.

[3] De Vincent, K., Yves, F., Dominique, J., Fritz, S. (2003). Coordonner Transports et Urbanisme. First Edition, Lausane: Presses Polytechniques et Universitaires Romandes.

[4] Liu, H. (2020). Smart Cities: Big Data Prediction Methods and Applications. Springer Nature, China. http://doi.org/10.1007/978-981-15-2837-8

[5] Morau, D. (2006). Modélisation des dispositifs de revalorisation énergétique des déchets solides et liquides. Thèse de doctorat, Université de la Réunion.

[6] Crozet, Y. (2016). Hyper-mobilité et politiques publiques: changer d'époque? Economica, pp. 190. Coll. Méthodes et Approches, Gérard Brun.

[7] Kouadria, N., Amara, F., Telaidjia, D. (2013). Déchets solides et environnement urbain à Annaba (Algérie): Approche managériale. Recherches et Etudes en 
Sciences Humaines, 4(7): 60-78.

[8] Salah, C. (2018). La gestion des Résidus Solides Urbains en Algérie: Quelles méthodes de traitement? Cas de la ville d'Annaba. Nature \& Technology Journal, A: Fundamental and Engineering Sciences, 10(1): 43-52.

[9] Bergeron, H., Castel, P., Sophie, D.Q. (2018). Le biais Comportementaliste. Presses de Sciences Po.

[10] Douard, P., Fareniaux, B., Helbronner, C., Campana, M., Chapelle, M.C., Cannard, P., Fournel, J., Bazin, P., Chouc, A. (2014). Mission d'évaluation de la politique publique et gestion des déchets par les collectivités territoriales. Con. Gé. de l'environnement et du développement durable et de l'économie.

[11] Guendouz, J., Buffière, P., Cacho, J., Carrère, M., Delgènes, J.P. (2010). Dry anaerobic digestion in batch mode: Design and operation of a laboratory-scale, completely mixed reactor. Waste Management, 30(10): 1768-1771. https://doi.org/10.1016/j.wasman.2009.12.024

[12] Chavanne, X., Frang, J.P. (2008). Le rendement énergétique de la production d'éthanol à partir de maïs Energy yield for the production of ethanol from corn. Comptes Rendus Geoscience, 340(5): 263-287. https://doi.org/10.1016/j.crte.2008.01.006

[13] Raynal, J., Delgenks, J.P., Moletta, R. (1997). Twophase anaerobic digestion of solid wastes by a multiple liquefaction reactors process. Bio Resource Technology, 65(2): 97-103. https://doi.org/10.1016/S09608524(98)00009-1

[14] Dupont, L., Accorsi, A. (2005). Explosion characteristics of synthesised biogas at various temperatures. Journal of Hazardous Materials, 136(3): 520-525. https://doi.org/10.1016/j.jhazmat.2005.11.105

[15] Kalia, V., Kumar A., Jain, S.R., Joshi, A.P. (1992). Biomethanation of plant materials. Bioresearch Technology, 41(3): 209-212. https://doi.org/10.1016/0960-8524(92)90003-G

[16] M'sadak, Y., Zoghlami, R.I. (2012). Caractérisations physicochimique, environnementale et energetique de la biomethanisation industrielle avicole en tunisie semiaride. Alg. Journal of Arid Environnement, 2(2): 16-27.

[17] Thonart, P., Diabate, S.I., Hiligsmann, S., Lardinois, M. (2000). Guide Pratique Sur La Gestion Des Déchets Ménagers et Des Sites D’Enfouissement Technique Dans Les Pays Du Sud. Collection Points de Repère.

[18] Banque mondiale. (2002). Projet Régional de Gestion des Déchets Solides dans les Pays du Mashreq et Maghreb: Rapport du pays d'Algérie.

[19] MATE. (2002). Plan National d'Actions pour l'Environnement et le Développement Durable (PNAE-DD).

[20] Hafid, N. (2002). Etude du compost de l'UPAO, des refus de compostage et des anciens dépotoire d'ordures ménagères de la ville d'Agadir. Laboratoire de Chimie minérale et Appliquée et Génie des procédés. Agadir, Maroc, Université IBN ZOHR, Agadir.

[21] Nissim, I., Shohat, T., Amichai, E. (2003). From dumping to recovery solid waste management in Israel. dans Ninth International waste management and Landfill Symposium, 6-10 October 2003, Cagliari, Italy.

[22] Sakulrat, J., Yuen, S.T.S., Joseph, J.B. (2003). Municipal solid waste management in Thailand: the current situation and possible short-term changes. Ninth International Waste Management and Landfill Symposium, Italy.

[23] Renou, S., Givaudan, J.G., Paulin, S., Moulin, P. (2008). Landfill leachate treatmant rewieu and opportrnuty. Journal of Hazardous Materials, 150(3): 468-493. https://doi.org/10.1016/j.jhazmat.2007.09.077

[24] Vilarinho, C., Castro, F., Gonçalves, M., Fernando, A.L. (2019). Wastes: Solutions, Treatments and Opportunities. Éditor Taylor \& Francis Limited.

[25] Boutrid, M.L., Kalla, M. (2015). La mobilité motorisée dans la ville de Batna, étude de la répartition spatiale des établissements de santé vis-à-vis du CHU : Approche par scénarios. BSGLg, 64: 83-92.

[26] Schwarcz, A. (2011). Municipal waste treatment methods: environmental, human health and nuisance effects. Library Briefing of the European Parliament.

[27] Bourguignon, D. (2015). Valorisation énergétique des déchets urbains: Opportunités et défis. service de recherche pour le parlement européen.

[28] Veld, K., Shogren, J.F. (2012). Shogren: Environmental federalism and environmental liability. Journal of Environmental Economics and Management, 63(1): 105119. https://doi.org/10.1016/j.jeem.2011.05.004

[29] ONU. (2000). Algérie, Bilan Commun de Pays Bureau d'Algérie.

[30] Lombrano, A. (2009). Cost efficiency in the management of solid urban waste. Resources, Conservation and Recycling, 53(11): 601-611. https://doi.org/10.1016/j.resconrec.2009.04.017

[31] Kah, E. (2003). La méthode d'évaluation contingente appliquée aux déchets urbains. L'Espace Géographique, 47-59. https://doi.org/10.3917/eg.321.0047

[32] Habik, S., El-Mahallawy, F. (2002). Fundamentals and Technology of Combustion. Elsevier Science, first edition, UK.

[33] Louai, N. (2009). Evaluation Energétique des déchets solides en Algérie, une solution climatique et un nouveau vecteur énergétique, Magistère en physique énergétique. Université Hadj Lakhdar Batna, Algérie. 